\title{
ABDERITID MARSUPIALS FROM THE MIOCENE OF PATAGONIA: AN ASSESSMENT OF FORM, FUNCTION, AND EVOLUTION
}

\author{
E. R. DUMONT, ${ }^{1}$ S. G. STRAIT, ${ }^{2}$ AND A. R. FRISCIA ${ }^{3}$ \\ 'Department of Anatomy, Northeastern Ohio Universities College of Medicine, Rootstown, Ohio 44272, \\ ${ }^{2}$ Department of Biological Sciences, Marshall University, Huntington, West Virginia 25755, and \\ ${ }^{3}$ Department of Organismal Biology, Ecology, and Evolution, University of California, Los Angeles, California 90035
}

\begin{abstract}
Abderitid marsupials are common in vertebrate-bearing deposits from the middle Miocene of Argentine Patagonia. Recent collections from the inland Pinturas Formation and slightly younger coastal Santa Cruz Formation have dramatically increased the number of abderitid specimens. These new collections permit a re-assessment of abderitid taxonomy as well as an investigation of the dietary habits of these unique small mammals. The vast majority of new specimens represent Abderites meridionalis; Pithiculites minimus is rare. Patterns of macrowear on the double-bladed, plagiaulacoid shearing complex suggest that abderitids used these teeth to prepare a variety of resistant food items as do modern marsupials with double-bladed shearing systems. Data summarizing molarshearing morphology and body size further suggest that A. meridionalis was a frugivore. The diet of the small P. minimus is equivocal, although it may represent a mixed feeder (frugivore/faunivore). A comparison of relative species richness and dietary adaptation between abderitids and palaeothentids (a closely related caenolestoid family that lacks the highly specialized shearing complex of abderitids) reveals distinct evolutionary patterns within the two lineages. Abderitids exhibit low species diversity. In contrast, palaeothentids are represented by 17 species, lack highly specialized shearing mechanisms, and typically exhibit molar morphologies that range from frugivory to faunivory and include mixed feeders. Both temporal and geographic variation are introduced as possible factors affecting differences in the relative abundance of abderitids and palaeothentids in the Pinturas and Santa Cruz Formations.
\end{abstract}

\section{INTRODUCTION}

$\mathbf{C}$ AENOLESTOID MARSUPIALS are a significant component of the Miocene small mammal fauna of Argentina. The families Palaeothentidae and Abderitidae contain the most diverse and abundant representatives of the superfamily, and are known from Deseaden through Santacrucian deposits throughout South America (e.g., Bown and Fleagle, 1993; Dumont and Bown, 1997; Marshall, 1976, 1990; Rae et al., 1996). Recent MACN-SUNY expeditions to the Pinturas Formation in the Rio Pinturas valley of Chubut Province and in the coastal Santa Cruz Formation (at Monte Observación and Monte León) have resulted in the recovery of 867 new specimens of abderitids, more than six times the number previously known.

Abderitids are among the few mammals that possess a plagiaulacoid dentition (Simpson, 1933). The enlarged lower incisors are followed by a wide diastema occupied by a series of vestigial teeth. Distal to the diastema are upper and lower hypertrophied, bladelike sectorial teeth (Fig. 1). Whereas the function of the blade-on-block shearing teeth of carpolestids and multituberculates has been investigated (Krause, 1982; Biknevicius, 1986), the double bladed system of abderitids has received only limited attention (Marshall, 1980). In addition to their peculiar dental morphology, the large numbers of abderitids (and indeed of caenolestoids) found at Pinturas, Monte Observación, and Monte León are of interest because of the long temporal sequence represented by those localities. Whether the new abderitid specimens represent a single species or many species, like the contemporary paleothentids (Bown and Fleagle, 1993), remains to be determined.

The goal of this paper is to describe the abderitids from the Pinturas Formation and Santa Cruz Formation localities at Monte Observación and Monte León and to address several related questions regarding their adaptations and evolution: 1) What do the $\mathrm{P} 4 / \mathrm{m} 1$ blade complex and details of molar morphology tell us about the dietary and feeding adaptations of these animals? 2) Were abderitids dietary generalists or specialists? 3) Given the many new fossils from a long geological sequence, what can be said about changes in abderitids over time? 4) In light of recent work on palaeothentid caenolestoids by Bown and Fleagle (1993), how do the diversity and relative abundance of abderitids and palaeothentids at these localities compare?

\section{ABBREVIATIONS}

Abbreviations used in the text are: MACN, Museo Argentino Ciencias Naturales "Bernardino Rivadavia," Buenos Aires, Argentina; SUNY, State University of New York at Stony Brook; $\mathrm{SC}$, collection from Provencia de Santa Cruz (in MACN). Lower case letters denote lower teeth (e.g., m1 for lower first molar), and capital letters refer to upper teeth (e.g., M2 for upper second molar).

\section{GEOLOGY}

From 1984 to 1994, joint MACN-SUNY expeditions yielded specimens from surface localities within the Pinturas and Santa Cruz Formations. Proposed ages for these units have varied (e.g., Marshall, 1976; Marshall et al., 1986; Bown and Larriestra, 1990), but the most recent analysis (Bown and Fleagle, 1993) places both unambiguously within the Santacrucian Land Mammal Age (middle Miocene). Recent radiometric evidence indicates that the inland Pinturas Formation is slightly older than the coastal Santa Cruz Formation (Fleagle et al., 1995). The paleosols found in both formations indicate moist conditions, and trace fossils of rhizoliths suggest a forested environment in some areas (Bown and Larriestra, 1990; Bown and Fleagle, 1993).

The Santa Cruz Formation occurs along the coast of the Santa Cruz province of Argentina, and is represented by localities at Monte Observación (north of the town of Río Gallegos) and Monte León (north of Monte Observación). This formation is composed primarily of coastal alluvial plains deposits, along with intermittent pyroclastic ash and gravel derived from the contemporaneous volcanic uplift of the Andes mountains. Some of these sediments developed into paleosols, whose lack of maturity suggests fairly continuous deposition (Bown and Fleagle, 1993).

The Pinturas Formation occurs approximately $400 \mathrm{~km}$ inland from the Santa Cruz Formation, in the northwest corner of Santa Cruz Province near the Río Pinturas. The Pinturas Formation differs from the Santa Cruz Formation in having more pyroclastic sediments, more mature paleosols, and two large erosional unconformities. The Pinturas Formation also contains paleodune deposits, which suggest more discontinuous, aeolian deposition (Bown and Larriestra, 1990). Pinturas Formation localities bearing abderitids include Estancia El Carmen (two localities), Portezuelo Sumich Norte, Portezuelo Sumich Sur, Estancia Los Toldos, Cauce Seca, Cerro de los Monos, Loma de la Lluvia, and 

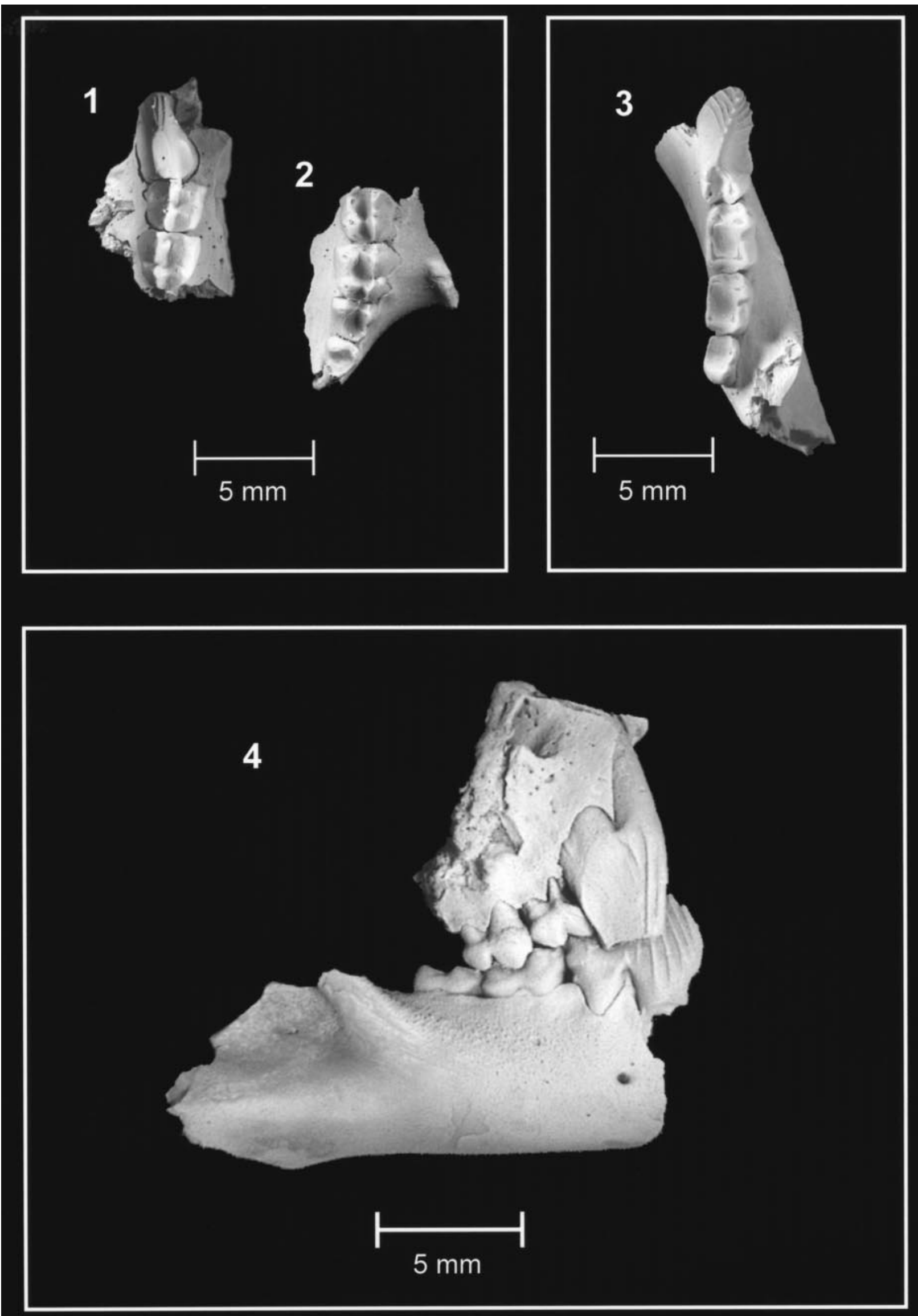
Loma de las Ranas (Estancia Ana Marie). The locality Estancia La Cañada occurs in sediments provisionally referred to the Pinturas Formation and is located between the upper Pinturas Valley and Atlantic coast (Bown and Fleagle, 1993).

The temporal sequence of localities within the unevenly exposed Pinturas Formation is based on lithologic correlations (Bown and Larriestra, 1990), while the presence of marker beds within the Santa Cruz Formation at both Monte Observación and Monte León allowed the temporal sequence of those localities to be based on superposition (Bown and Fleagle, 1993). Within both the Pinturas and Santa Cruz Formations, the absolute separation of localities in time was determined using the relative maturity of the paleosols contained within each formation (Bown and Larriestra, 1990; Bown and Fleagle, 1993). The relationship between the Pinturas and Santa Cruz Formations is based on radiometric data (Bown and Fleagle, 1993; Fleagle et al., 1995).

\section{MATERIALS AND METHODS}

Several techniques were used to document the morphological diversity among the new abderitid specimens and to compare them with other living and extinct marsupial species. To analyze variation in tooth size within the abderitid sample, lengths and widths of individual teeth were measured using a dissecting microscope equipped with an ocular micrometer. The microscope was calibrated at the beginning of each measurement session and repeated measurements were taken to reduce inter- and intraobserver error. Changes in tooth size within species over time were investigated in conjunction with relative temporal value data established for the Pinturas (Bown and Larriestra, 1990) and Santa Cruz localities (Bown and Fleagle, 1993).

Patterns of macroscopic wear on the hypertrophied P4/m1 shearing blades were documented using a camera lucida attached to a dissecting microscope. One abderitid wear series (sampled from Portezuelo Sumich Sur) was compared to a series from Phalanger orientalis, a modern marsupial with a double-bladed plagiaulacoid shearing complex. The wear patterns in these marsupials were also compared to previously published data for multituberculates (Krause, 1982) and carpolestids (Biknevicius, 1986). Multituberculates and carpolestids exhibit a different plagiaulacoid shearing morphology in which a bladelike lower tooth occludes against an enlarged, flat upper tooth.

Body mass was reconstructed, as it is an important ecological parameter that impacts upon affecting morphology, physiology, and behavior (Fleagle, 1978; Peters, 1983; Schmidt-Nielsen, 1984; Damuth and MacFadden, 1990). The association of size and behavioral characteristics is central to paleoecological studies as body mass is one of the few features that can easily be estimated from the fossil record (Jungers, 1990). Several studies (Kay, 1975, 1984; Kay and Hylander, 1978) demonstrate an association between body mass and dietary preference among primates. A similar pattern exists among extant marsupials where faunivores weigh below $450 \mathrm{~g}$ and folivores exceed $600 \mathrm{~g}$ (Smith and Lee, 1984). Body mass of fossil species was reconstructed from lower second molar area (length $\times$ width) using a baseline composed of 27 extant marsupial species that range in body mass from approximately 10 to $1500 \mathrm{~g}$ (Table 1). Linear regression was used to establish a predictive equation from the extant sample for estimating body mass in fossil abderitids, palaeothentids, and caenolestids.
TABLE 1-Extant species included in this study. The sample size for body mass $\left(\mathrm{n}_{\mathrm{M}}\right)$, mean body mass (in grams), and mean $\mathrm{m}^{2}$ area (length $\times$ width) are provided for species used to establish predictive regression equation between mass and tooth size. Sample size is provided where $\mathrm{m}^{2}$ shearing crest development was measured $\left(\mathrm{n}_{\mathrm{S}}\right)$.

\begin{tabular}{|c|c|c|c|c|}
\hline Taxa & $\mathrm{n}_{\mathrm{M}}$ & $\mathrm{n}_{\mathrm{s}}$ & $\mathrm{m}_{2}$ area & Body mass \\
\hline \multicolumn{5}{|l|}{ Didelphidae } \\
\hline $\begin{array}{l}\text { Marmosa karimii } \\
\text { Monodelphis domestica } \\
\text { Monodelphis demidiata } \\
\text { Didelphis marsupialis } \\
\text { Philander opossum pallidus } \\
\text { Philander opossum opossum } \\
\text { Lutreolina crassicaudata } \\
\text { Chironectes minimus } \\
\text { Caluromys philander }\end{array}$ & $\begin{array}{l}1 \\
8 \\
1 \\
5 \\
3 \\
2 \\
2 \\
2 \\
2\end{array}$ & $\begin{array}{l}- \\
- \\
- \\
- \\
-\end{array}$ & $\begin{array}{r}1.74 \\
3.04 \\
1.85 \\
20.82 \\
5.84 \\
7.80 \\
5.97 \\
12.48 \\
5.17\end{array}$ & $\begin{array}{r}15^{1} \\
97^{1} \\
50^{1} \\
1,520^{1} \\
507^{1} \\
340^{1} \\
218^{1} \\
700^{1} \\
316^{1}\end{array}$ \\
\hline \multicolumn{5}{|l|}{ Caenolestidae } \\
\hline $\begin{array}{l}\text { Caenolestes convelatus } \\
\text { Caenolestes fuliginosus } \\
\text { Caenolestes caniventer } \\
\text { Lestoros inca }\end{array}$ & $\frac{1}{3}$ & $\begin{array}{r}- \\
10 \\
2\end{array}$ & $\begin{array}{l}2.28 \\
2.53 \\
\frac{1}{2.10}\end{array}$ & $\begin{array}{l}25^{2} \\
37^{2} \\
-24^{2}\end{array}$ \\
\hline $\begin{array}{l}\text { Dasyuridae } \\
\text { Antechinus stuartii } \\
\text { Sminthopsis crassicaudata } \\
\text { Dasyuroides byrnei } \\
\text { Dasyurus geoffroii } \\
\text { Dasyurus hallucatus } \\
\text { Dayscercus cristicauda }\end{array}$ & $\begin{array}{r}20 \\
14 \\
2 \\
2 \\
2 \\
1\end{array}$ & $\begin{array}{l}20 \\
14 \\
- \\
- \\
-\end{array}$ & $\begin{array}{r}2.09 \\
1.32 \\
5.56 \\
14.08 \\
10.65 \\
4.72\end{array}$ & $\begin{array}{r}26^{3} \\
15^{4} \\
110^{5} \\
1,100^{6} \\
525^{6} \\
75^{7}\end{array}$ \\
\hline \multicolumn{4}{|l|}{ Peramelidae } & $690^{8}$ \\
\hline \multicolumn{5}{|l|}{ Notoryctidae } \\
\hline $\begin{array}{l}\text { Petauridae } \\
\text { Gymnobelideus leadbeateri } \\
\text { Petaurus breviceps } \\
\text { Petaurus australis } \\
\text { Pseudocheirus archeri }\end{array}$ & $\begin{array}{r}2 \\
22 \\
1 \\
5\end{array}$ & $\begin{array}{l}\overline{20} \\
-\end{array}$ & $\begin{array}{r}2.94 \\
2.59 \\
6.44 \\
13.42\end{array}$ & $\begin{array}{r}145^{9} \\
130^{10} \\
549^{11} \\
1,092^{6}\end{array}$ \\
\hline $\begin{array}{l}\text { Burramyidae } \\
\text { Cercartetus nanus } \\
\text { Acrobates pygmaeus }\end{array}$ & $\begin{array}{r}9 \\
16\end{array}$ & 16 & $\begin{array}{l}1.67 \\
0.74\end{array}$ & $\begin{array}{l}25^{12} \\
12^{13}\end{array}$ \\
\hline \multicolumn{5}{|l|}{ Macropodidae } \\
\hline
\end{tabular}

${ }^{1}$ from museum records for measured specimens; ${ }^{2}$ Kirsch and Waller, 1979 ${ }^{3}$ Nagy et al., 1978; ${ }^{4}$ Morton, 1978; ${ }^{5}$ MacMillen and Dawson, 1986; ${ }^{6}$ Strahan, 1995; ${ }^{7}$ Gibson and Cole, 1992; ${ }^{8}$ Lyne, 1964; ${ }^{9}$ Smith, 1984; ${ }^{10}$ Smith, 1982; ${ }^{11}$ Craig, 1985; ${ }^{12}$ Ward, 1990; ${ }^{13}$ Turner, 1984.

Whereas body mass provides a rough indication of diet, detailed analysis of molar morphology is often necessary to distinguish between small frugivores and faunivores, and large frugivores and folivores. Comparative morphometric analyses of molar shearing crests have been used to demonstrate the tendency for increased shearing capabilities in faunivores and folivores relative to frugivores (Kay, 1975; Kay and Covert, 1986; Strait, 1993a). To provide modern analogs, shearing crests of two extant faunivorous caenolestoids (Caenolestes caniventer and Lestoros incus) were added to an existing sample of frugivorous diprotodonts ( $A c$ robates pygmaeus and Petaurus breviceps) and faunivorous dasyuromorphs (Antechinus stuartii and Sminthopsis crassicaudata) (Strait, 1993a). Shearing development was also measured from a

$\leftarrow$

FIgURE 1-Maxillary and dentary fragments of A. meridionalis from the Pinturas Formation illustrating the interpretation of tooth homology used here. 1. Occlusal view of right maxillary fragment (MACN-SC 498) with P4, M1-M2. 2. Occlusal view of left maxillary fragment (MACNSC1048) with M1-M4. 3. Occlusal view of right dentary fragment (MACN-SC648) with m1-m4. 4. Buccal view of right maxillary (MACNSC498) and dentary fragments (MACN-SC431) placed in occlusion. 
- Abderites crispus

- A. meridionalis

- A. pristinus
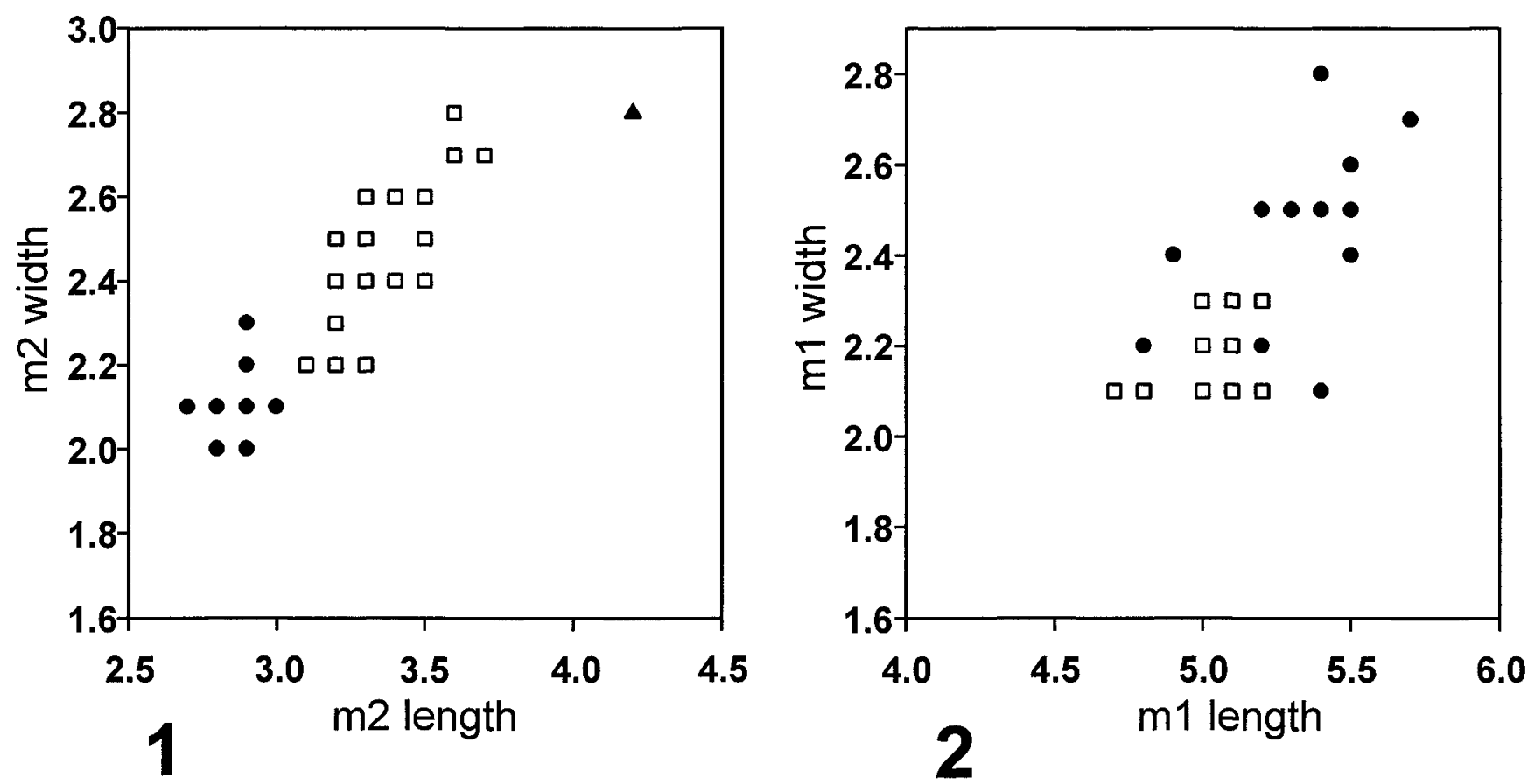

FIGURE 2-Differences in lower second (1) and first (2) molar area (length $\times$ width) on which the original diagnoses of Abderites meridionalis, A. crispus, and A. pristinus were based (data from Marshall, 1976, 1990).

sample of fossil caenolestoids representing each of the three families.

Lengths of six shearing crests (Crests 1-6 of Kay and Hiiemae, 1974), m2 area (digitized from occlusal views of tooth perimeters), and $\mathrm{m} 2$ length of both extant and fossil taxa were measured with a Reflex Microscope at $20 \times$ magnification (for a further

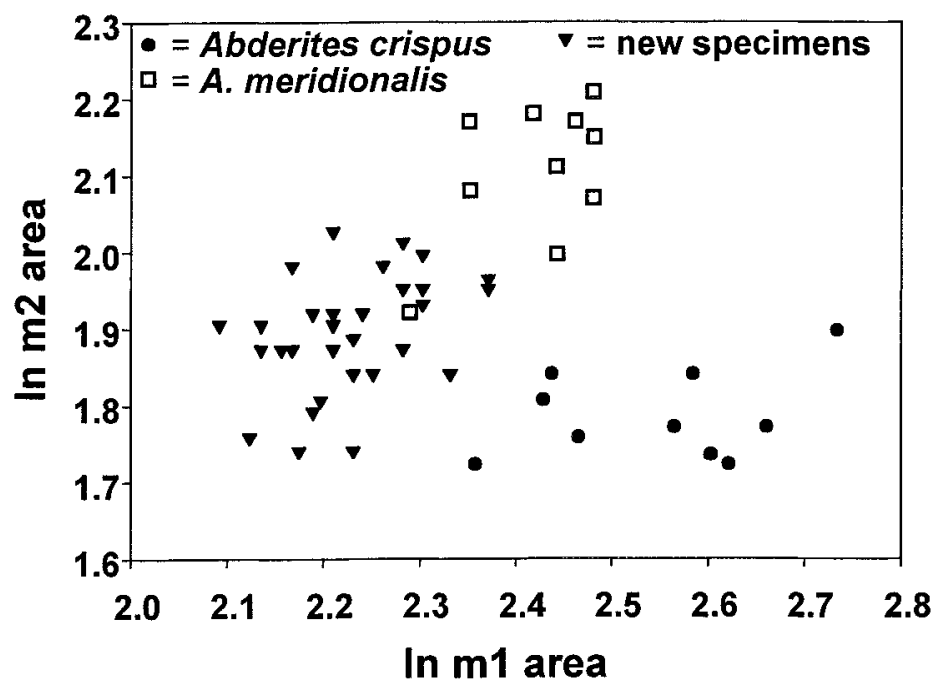

FIGURE 3-The distribution of $\ln (\mathrm{m} 1$ area) against $\ln (\mathrm{m} 2$ area) in Abderites meridionalis, A. crispus (data from Marshall, 1976, 1990), and new specimens from the Pintauras and Santa Cruz Formations. discussion of the methodology see Strait, 1993b). Following Strait (1993a) two ratios were constructed: 1) the sum of lengths of Crests 1-6 divided by the square root of tooth area (digitized from occlusal views of tooth perimeters) provides a shearing ratio based on area (SRA), and 2) the sum of lengths of Crests 1-6 divided by molar length provides a shearing ratio based on length (SRL). Shearing ratios based on these size surrogates (i.e., the square root of tooth area and tooth length) tend to underestimate the shearing potential of faunivorous taxa and can yield slightly different results (Strait, 1993a). Both ratios are examined here to produce the most accurate interpretations. Shearing ratios derived from the fossil sample were compared to those of living frugivores and faunivores as a means of reconstructing their dietary habits.

\section{SYSTEMATIC PALEONTOLOGY}

Superorder MARSUPIALIA Illiger, 1811 Order PAuCITUBERCUlATA Ameghino, 1894

Family ABDERITIDAE Ameghino, 1889

Genus ABDERITES Ameghino, 1887

ABDERITES MERIDIONALIS Ameghino, 1887, p.5

Figures 4-6, Tables 2, 3

A. meridionalis AMEGHINO, 1887, p. 5; 1889, p. 269, pl. 1, figs. 6-8E; 1890 , p. 149 , figs. $1-3 ; 1894$, p. 339 , fig. $31 ; 1898$, p. 186 , fig. 491 II; 1903 , p. $142,155,176$, 178, figs. 64 , 78, 105, 107; 1904, p. 44, fig. 29; Schlosser, 1925, p. 28, fig. 44A-C; Kraglievich, 1953, p. 54, figs. 6B, H. Marshall, 1990, p. 28, pl. 8-10.

A. crasignathus AMEGHINO, 1891a, p. 248.

A. crassiramus AMEGHINO, 1893, p. 80, fig. 4; 1894, p. 339, fig. 30; 1898, p. 186, fig. 49 III; 1903, p. 87, figs. 4, 39. 


\section{- Pinturas \\ $\square$ Monte Observación \\ $\triangle$ Monte Leon}
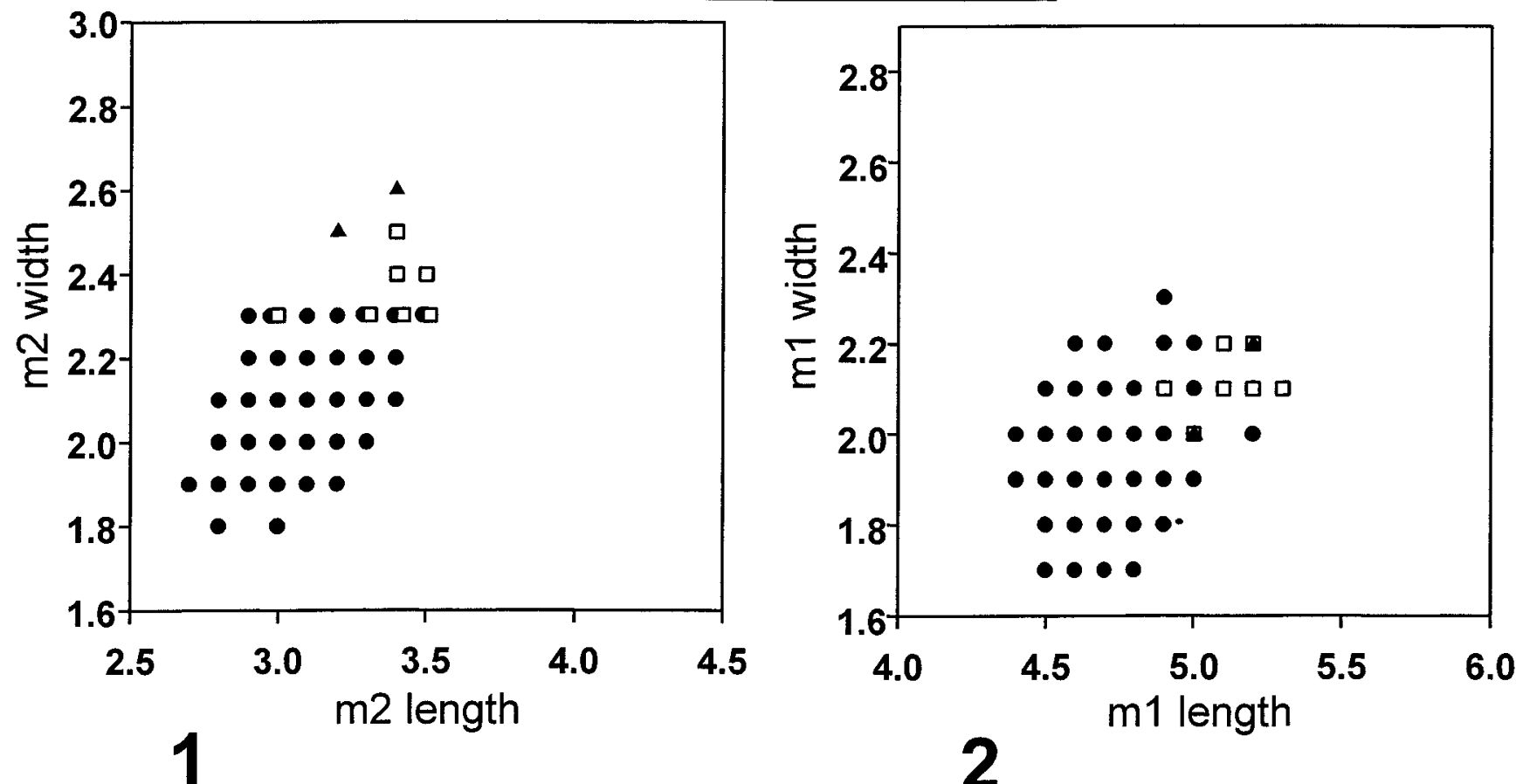

Figure 4-The area (length $\times$ width) of Abderites lower second (1) and first (2) molars from the Pinturas Formation and Santa Cruz Formation localities at Monte Observación and Monte León.

A. crassignathus SINCLAIR, 1906, p. 439, pl. 64, figs. 3, 3A, text-figs. 9A, B; KRAGLIEVICH, 1953, p. 52, figs. 5A, G.

A. serratus AMEGHINO, 1891a, p. 248; 1894, p. 340.

A. tenuissimus AMEghino, 1891b, p. 304; 1894, p. 340.

A. crispus AmEghino, 1902a, p. 77 (nomen nudem); 1902b, p. 120, figs. 2, 3, tables 1, 3; Simpson, 1932, p. 5, fig. 3; Paulo Couto, 1952, p. 18, figs. 5C, 6B-C; Kraglievich, 1953, p. 52; Marshall, 1976, p. 60 , figs. 2,3 .

A. crispulus Ameghino, 1902b, p. 120; Kraglievich, 1953, p. 52, fig. $6 \mathrm{~F}$.

Emended diagnosis.- Lower second molar smaller in length and breadth than in Abderites pristinus.

Type.-Holotype, MACN 12, a right ramal fragment with m1$\mathrm{m} 3$ and $\mathrm{m} 4$ alveolus (Ameghino, 1887).

New material.- Specimen numbers and measurements available from primary author.

Discussion.- In the most recent revision of the Abderitidae, Marshall (1976) recognized three species of the genus Abderites: Abderites crispus and $A$. pristinus from Colhuehuapian deposits, and $A$. meridionalis from the Santa Cruz Formation. Whereas A. pristinus was represented by a mandibular fragment containing a single lower second molar, A. crispus was represented by 16 specimens. More recent collecting efforts in the Río Frías Formation in Chile (Marshall, 1990) increased the total number of available A. meridionalis specimens to 43. Marshall (1976) presented a diagnosis of these species based on differences in lower molar size. Figure 2 illustrates that $A$. pristinus has the largest $\mathrm{m} 2$, while $\mathrm{m} 2$ $\mathrm{m} 4$ of $A$. meridionalis are intermediate in size and those of $A$. crispus are smallest. In contrast, the $\mathrm{m} 1$ of $A$. meridionalis tends to be shorter and narrower than that of A. crispus. The $\mathrm{m} 2$ is relatively large with respect to $\mathrm{m} 1$ in A. meridionalis, and relatively small in A. crispus (Fig. 3).
The size distribution of the Abderites lower molar teeth from the Pinturas Formation and Santa Cruz Formation localities at Monte Observación and Monte León is illustrated in Figure 4. Lower second molar area of the Abderites specimens from Pinturas, Monte Observación, and Monte León overlap those of both A. meridionalis and A. crispus. Whereas the Monte León m2s are distinctly longer than those from the Pinturas Formation, the gap between them is bridged by specimens from Monte Observación. Similarly, the distribution of the new $\mathrm{m} 1$ lengths overlap the lower end of the distribution described for A. meridionalis and A. crispus. However, while absolute tooth size offers little to illuminate the affinities of the new Abderites specimens, the new material is most similar to A. meridionalis in the relative size of $\mathrm{m} 1$ and $\mathrm{m} 2$ (Fig. 3). Although they are generally smaller in absolute size, the Pinturas and Santa Cruz specimens effectively replicate the ratio between $\mathrm{m} 1$ and $\mathrm{m} 2$ seen in A. meridionalis on a slightly smaller scale.

With the addition of the new material from the Pinturas and Santa Cruz Formations, the previously clear distinction between A. meridionalis and A. crispus in tooth size is replaced by a picture of morphological variation within a continuous size distribution. Marshall (1976) noted subtle variations in tooth crown morphology between A. meridionalis and A. crispus (e.g., more robust dentary, weaker loph development, and smaller M2 cuspule in A. crispus), but he did not consider these differences diagnostic. In an examination of the new fossils along with casts and descriptions of other Abderites species, no discrete characters were found that could be used to refer the new specimens exclusively to either $A$. meridionalis or A. crispus. Therefore, we refer the Pinturas, Monte Observación, and Monte León Abderites specimens to Abderites meridionalis (Ameghino, 1887) on the basis of their similarity in the relative sizes of $\mathrm{m} 1$ to $\mathrm{m} 2$. 

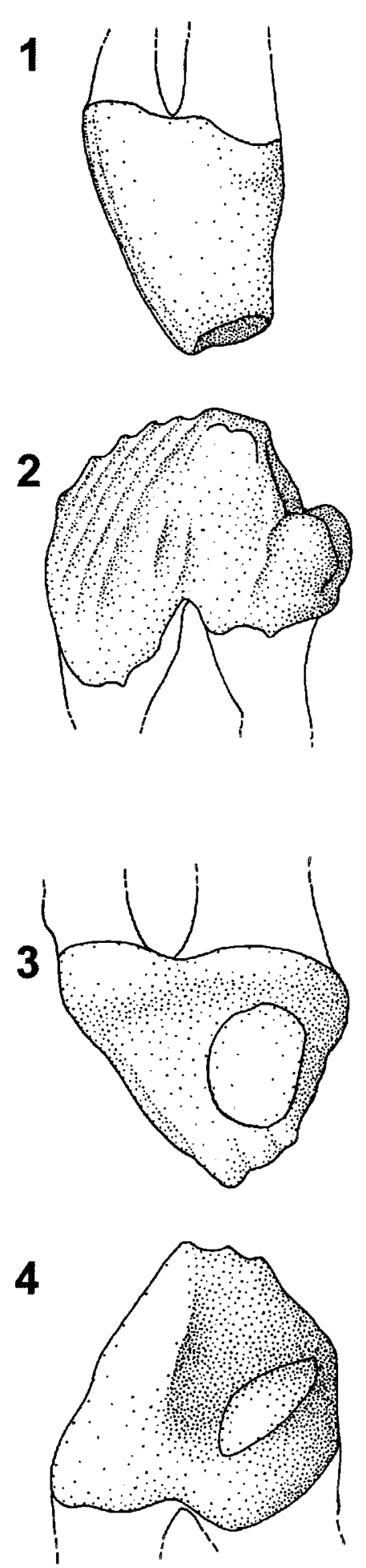
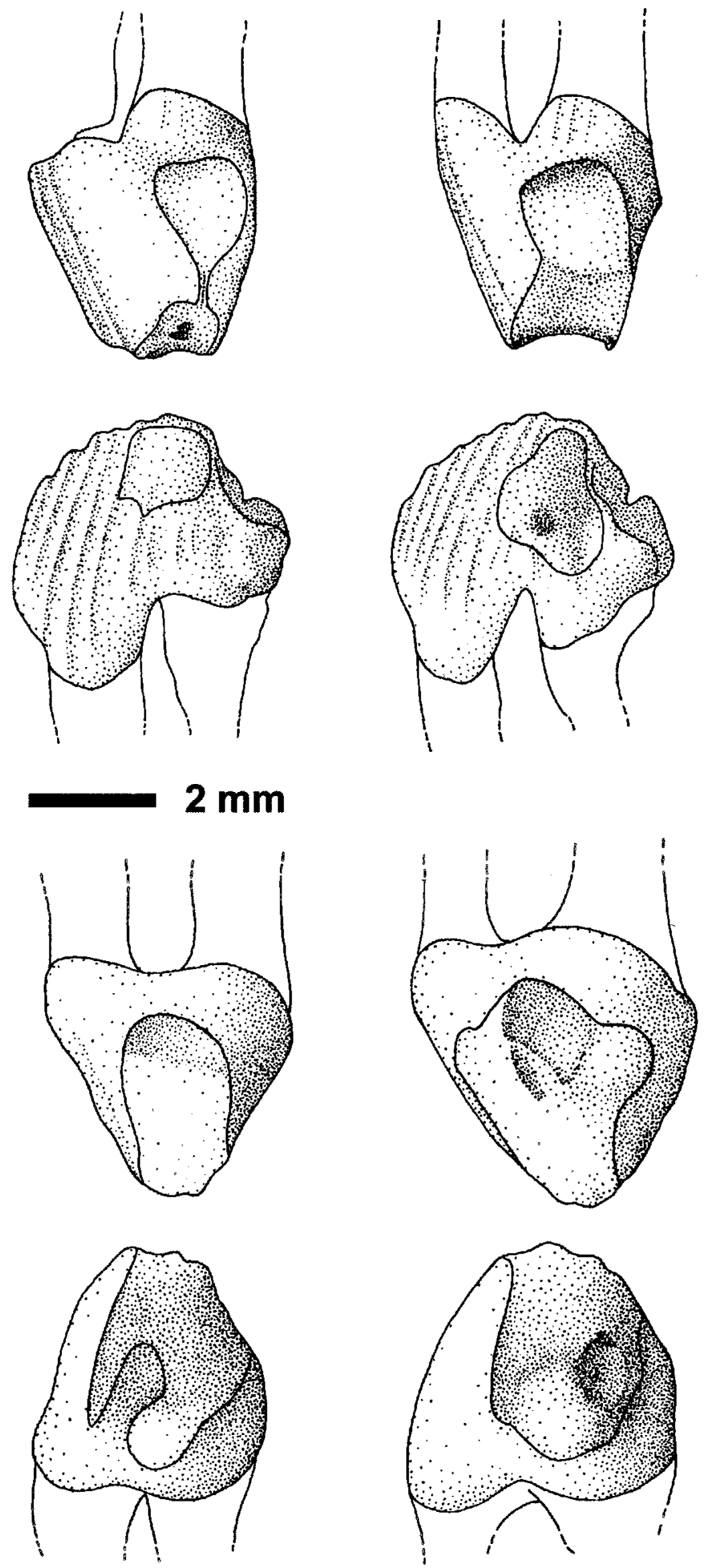

FIGURE 5-A series illustrating the progression of wear on left upper and lower shearing blades of Abderites meridionalis (1 and 2) and Phalanger orientalis (3 and 4). Lingual views of upper blades and buccal views of lower blades are shown. Within each series (1-4), wear increases from left to right.

It is also likely that the edentulous specimen referred to $A b$ derites sp. (MLP 68-I-17-210; Marshall,1976; Marshall and Pascual, 1977) is A. meridionalis. The specimen is attributed to lower Santa Cruz beds near Calafate (Patagonia, Argentina) and, like the fossils from the Pinturas Formation, is considered to be early Santacrucian in age. Marshall suggested that the isolated specimen represented a species that is intermediate in both time and size between A. crispus and A. meridionalis. Rather than 

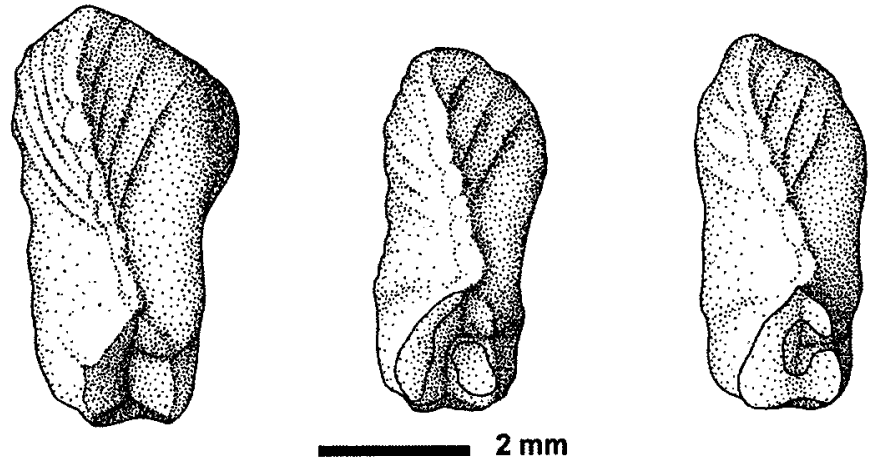

FIGURE 6-A series illustrating the unworn morphology (left) and progression of wear (middle to right) on the talonid of Abderites meridionalis lower right first molars. Early stages of wear (middle) expose dentine on the entoconid and contiguous lingual talonid crest and on the hypoconid. These facets coalesce later in the wear process (right).

supporting a truly intermediate species, this specimen fits easily within the large sample from the temporally intermediate Pinturas Formation, demonstrating that A. meridionalis was long-lived, varied in size, and contained a degree of morphological variation that is easily contained within a single species.

Genus Pithiculites Ameghino, 1902b

PithicUlites MiNimus Ameghino, 1902b Figure 7, Table 4

Pithiculites minimus (partim) AMEGHINo, 1902a, p. 76 (nomen nudem); 1902b, p. 74; 1906, p. 425, fig. 318a; SIMPSON, 1932, p. 3; REIG, 1955, p. 62; Marshall, 1976.

Eomanodon multituberculatus AMEGHINO, 1902b, p. 119.

Micrabderites williamsi SIMPSON, 1932, p. 6, fig. 4.

TABLE 2-Fossil species used in this study. The sample size $\left(\mathrm{n}_{\mathrm{M}}\right)$ and mean $\mathrm{m} 2$ area ( $\mathrm{m} 2$ length $\times$ width) are presented where body mass (in grams) was reconstructed. Sample size is provided for species in which $\mathrm{m} 2$ shearing crest development was measured $\left(\mathrm{n}_{\mathrm{s}}\right)$. Inferred diet (Diet) is based on shearing ratio and body mass data.

\begin{tabular}{|c|c|c|c|c|c|}
\hline Taxa & $\mathrm{n}_{\mathrm{M}}$ & $\mathrm{n}_{\mathrm{s}}$ & $\mathrm{m}_{2}$ area & $\begin{array}{l}\text { Body } \\
\text { mass }\end{array}$ & Diet \\
\hline \multicolumn{6}{|l|}{ Caenolestidae } \\
\hline Stiloterium dissimile & 3 & 3 & 1.48 & $24 \mathrm{~g}$ & Mixed \\
\hline Phonocdromus gracilis & 2 & 2 & 1.04 & $13 \mathrm{~g}$ & Insects \\
\hline \multicolumn{6}{|l|}{ Abderitidae } \\
\hline Abderites meridonalis & 10 & 10 & 5.76 & $248 \mathrm{~g}$ & Fruit \\
\hline Pitheculites minimus & 5 & 5 & 1.54 & $25 \mathrm{~g}$ & Mixed \\
\hline \multicolumn{6}{|l|}{ Palaeothentidae } \\
\hline Acdestis lemairei & $18^{1}$ & 3 & 5.13 & $203 \mathrm{~g}$ & Mixed \\
\hline Acdestis oweni & $113^{1}$ & 5 & 6.71 & $323 \mathrm{~g}$ & Fruit \\
\hline Acdestoides praecursor & $1^{1}$ & - & 6.60 & $314 \mathrm{~g}$ & - \\
\hline Acdestoides bonapartei & $1^{1}$ & - & 6.09 & $273 \mathrm{~g}$ & - \\
\hline Carlothentes chubutensis & $1^{1}$ & - & 13.2 & $1,039 \mathrm{~g}$ & - \\
\hline Hondathentes cazador & $1^{1}$ & - & 3.68 & $114 \mathrm{~g}$ & - \\
\hline Palaeothentes aratae & $13^{1}$ & 2 & 11.34 & $799 \mathrm{~g}$ & Fruit \\
\hline Palaeothentes intermedius & $30^{1}$ & 3 & 4.67 & $173 \mathrm{~g}$ & Insects \\
\hline Palaeothentes lemoinei & $28^{1}$ & 2 & 7.18 & $363 \mathrm{~g}$ & Insects \\
\hline Palaeothentes marshalli & $17^{1}$ & 2 & 4.34 & $152 \mathrm{~g}$ & Fruit \\
\hline Palaeothentes migueli & $23^{1}$ & 2 & 2.49 & $58 \mathrm{~g}$ & Fruit \\
\hline Palaeothentes minutus & $112^{1}$ & 10 & 3.06 & $83 \mathrm{~g}$ & Insects \\
\hline Palaeothentes pascuali & $6^{1}$ & 1 & 2.25 & $49 \mathrm{~g}$ & Insects \\
\hline Palaeothentes primus & $1^{1}$ & - & 5.20 & $208 \mathrm{~g}$ & - \\
\hline Pilchenia lucina & $1^{1}$ & - & 6.09 & $273 \mathrm{~g}$ & - \\
\hline Propalaeothentes hatcheri & $1^{1}$ & - & 3.15 & $87 \mathrm{~g}$ & - \\
\hline Propalaeothentes lepidus & $5^{1}$ & 1 & 4.30 & $150 \mathrm{~g}$ & Insects \\
\hline Trelewthentes rothi & $18^{1}$ & 1 & 5.66 & $241 \mathrm{~g}$ & Insects \\
\hline
\end{tabular}

${ }^{1}$ measurements from Brown and Fleagle, 1993.

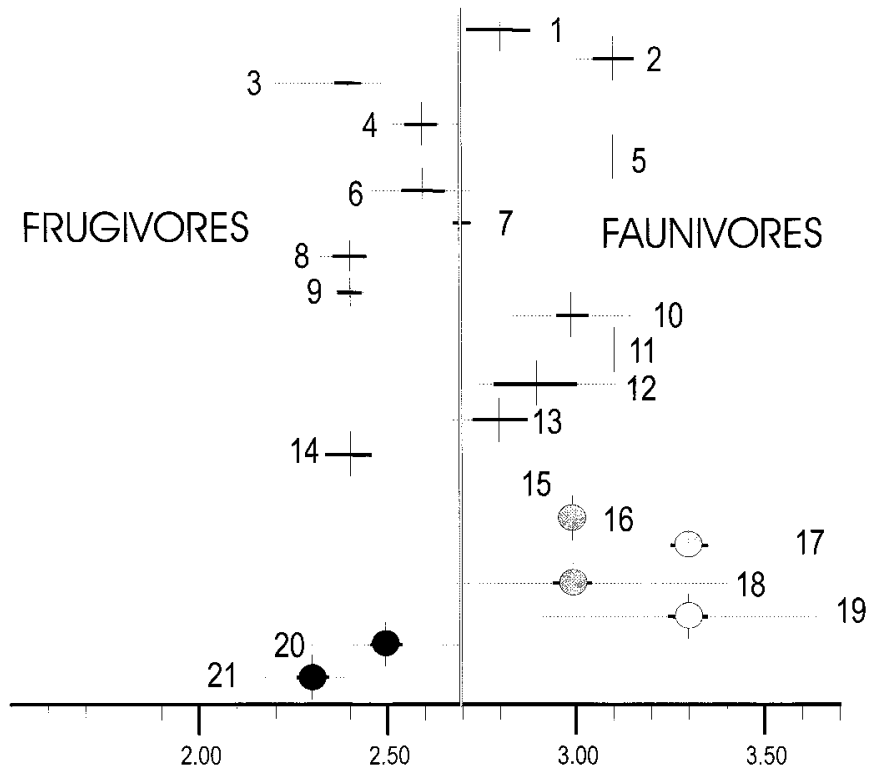

Sum of Crests 1-6 / Tooth Area (SRA)

FIGURE 7-The sum of shearing Crests 1-6 divided by tooth area (SRA). Means are presented for extant frugivores (dark circles) and faunivores (light circles) and fossil taxa (vertical lines). Horizontal bars represent 95 percent confidence limits and horizontal dotted lines represents observed ranges. Species are: $1=$ Stilotherium dissimile, $2=$ Phonocodromus gracilis, $3=$ Abderites meridionalis, $4=$ Pithiculites minimus, $5=$ Trelewthentes rothi, $6=$ Acdestis oweni, $7=$ A. lemairei, $8=$ Palaeothentes marshalli, $9=P$. migueli, $10=P$. minutus, $11=$ $P$. pascuali, $12=P$. intermedius, $13=P$. lemoine, $14=P$. aratae, $15=$ Propalaeothentes lepidus, $16=$ Lestoros inca, $17=$ Caenolestes caniventer, $18=$ Antechinus stuartii, $19=$ Sminthopsis crassicaudata, $20=$ Petaurus breviceps, $21=$ Acrobates pygmaeus .

Type.-Holotype, MACN 52-660, left maxillary fragment with fragmentary M1 alveolus, M2-M3, M4 alveoli (Ameghino, 1902).

New material.-Specimen numbers and measurements available from primary author.

Discussion.-Although the overwhelming majority of abderitid specimens recovered at Pinturas Formation localities are of $A b$ derites, six specimens (including one fragmentary tooth) of Pithiculites were identified in collections from Portezuelo Sumich Norte, Cerro de los Monos, Loma de la Lluvia, Loma de las Ranas, and Portezuelo Sumich Sur. These specimens are identical in both morphology and size to Pithiculites minimus.

\section{DIETARY RECONSTRUCTION}

In order to reconstruct diet in these unique fossil forms, three parameters were examined; the morphology and wear of the P4/ $\mathrm{m} 1$ shearing complex, estimates of body mass, and measurements of molar shearing crest development. Each of these techniques offer a unique perspective on abderitid dental function.

The P4/m1 shearing complex.-The progression of wear on the plagiaulacoid shearing blades of Abderites meridionalis and Phalanger orientalis is illustrated in Figure 5. In Abderites the apical cusps of the lower blade (m1) and their associated lateral striations show only slight wear even in the most worn specimens. On the $\mathrm{m} 1$, a small wear facet first develops on the buccal side of the tooth at the postero-superior aspect of the trigonid, similar to that seen on carnivoran carnassials (Taylor and Hannam, 1987). Over the course of wear this facet enlarges toward the cervical margin, but never encroaches upon the apex of the tooth. The 
corresponding wear on the upper blade (P4) first appears on the apico-lingual surface. This primary facet is crescentic in shape, with its superior edge becoming progressively deeper and more concave as wear progresses. In later wear stages, a second, ovoid wear facet appears at the slightly inflated lingual base of the tooth. In heavily worn specimens these two facets coalesce to form a wide swath down the lingual surface of the blade.

When maxillary and mandibular specimens are placed in occlusion (Fig. 1.4), it is evident that the wear facets on the upper and lower blades mirror the points of contact between them. The tip of the upper blade was worn as it sheared past the inflated bucco-cervical aspect of the lower blade. Furthermore, at full occlusion the postero-buccal surface of the trigonid came into occlusion with the inflated lingual base of the upper blade, accounting for the second, more superior wear facet on the uppers, and the small buccal wear facet seen on the lowers.

The presence of a well-developed talonid is a unique feature of abderitid lower blades (m1). In Phalanger, multiuberculates, and carpolestids the entire lower tooth is modified into a blade. In abderitids only the trigonid is modified and the talonid remains distinctly molariform. The talonid cusps are identified as the hypoconid and entoconid, and the buccal crest has been provisionally termed the cristid obliqua (Marshall, 1976). The distribution and progression of wear on the talonids (Fig. 6) illustrates that these surfaces fulfilled a functional role. Wear was initiated in two areas; on the hypoconid and cristid obliqua (buccal crest) extending to the modified trigonid, and on the entoconid. As the lower teeth moved into centric occlusion and the M1 protocone came to lie in the $\mathrm{m} 1$ talonid basin (see Fig. 1.4), the extended plane formed by the P4 blade and internal surfaces of the M1 paracone and metacone sheared against the elongated buccal surface formed by the hypoconid and presumptive cristid obliqua. In addition to these exaggerated shearing surfaces, smaller grinding and crushing facets formed on the internal aspects of the hypoconid and entoconid, respectively. As wear progressed, the wear facets coalesced until the entire rim of the talonid basin flattened to expose a dentine ring.

Unworn sectorial teeth (Fig. 5) of Phalanger are relatively wider than those of abderitids and the ridges extending from the apical cusps are less pronounced. In addition, the apices of Phalanger blades exhibit more wear than those of abderitids although their original outlines and apical cusps are maintained. Despite these differences, the location and progression of wear on Phalanger blades is quite similar to that of abderitids. Wear on the lower tooth begins as a postero-buccal facet and eventually extends from the crest of the blade to nearly the cervical margin. A small dentine island may appear late in the wear series at the site of the initial wear surface. Wear first occurs on upper blades midway up the postero-lingual aspect of the tooth. This facet progressively enlarges, eventually occupying most of the lingual aspect of the tooth and extending to the apex of the blade. In Phalanger, as in the abderitids, the wear surfaces correspond to points of occlusion between the opposing edges of complimentary upper and lower blades.

Wear on the shearing blades of carpolestids and multituberculates differs significantly from that seen in Abderites and Phalanger. On the lower blades of carpolestids (p4), wear is entirely apical and the originally rounded blade soon becomes flat (Biknevicius, 1986). The small apical cusps are quickly obliterated during the course of wear. The wear on multituberculate blades (m1) is apical as it is in carpolestids, but instead of flattening the tooth, it begins posteriorly and migrates anteriorly over time (Krause, 1982). This results in a tooth that keeps a generally rounded shape throughout its wear stages. As in carpolestids, the apical cusps in multituberculates are obliterated as wear progresses.

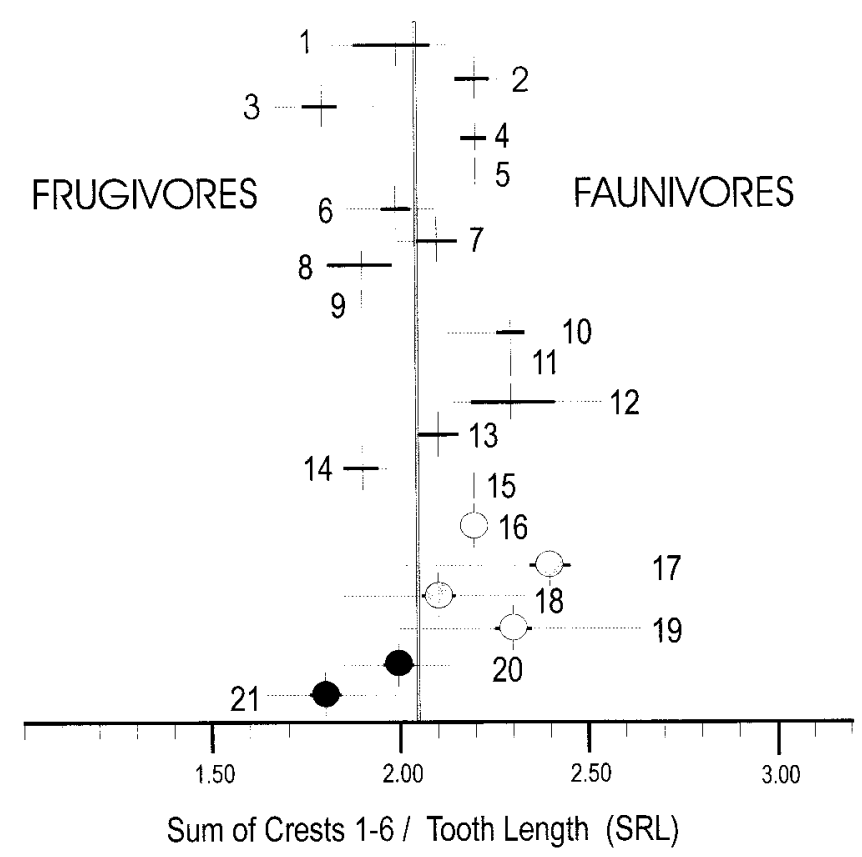

FIGURE 8 - The sum of lengths of shearing Crests 1-6 divided by tooth length (SRL). Means are presented for extant frugivores (dark circles), and faunivores (light circles), and fossil taxa (vertical lines). Horzontal bars represent 95 percent confidence limits and horizontal dotted lines represents observed ranges. Species are: $1=$ Stilotherium dissimile, 2 $=$ Phonocodromus gracilis, $3=$ Abderites meridionalis, $4=$ Pithiculites minimus, $5=$ Trelewthentes rothi, $6=$ Acdestis oweni, $7=A$. lemairei, $8=$ Palaeothentes marshalli, $9=P$. migueli, $10=P$. minutus, $11=P$. pascuali, $12=P$. intermedius, $13=P$. lemoinei, $14=$ P. aratae, $15=$ Propalaeothentes lepidus, $16=$ Lestoros inca, $17=$ Caenolestes caniventer, $18=$ Antechinus stuartii, $19=$ Sminthopsis crassicaudata, $20=$ Petaurus breviceps, $21=$ Acrobates pygmaeus.

Body size.-Among the extant marsupials body mass and lower second molar area is highly correlated $(r=0.933 ; p<0.001)$. The predictive regression equation derived from the extant data set $\left[\ln\right.$ body mass $=2.419+\left(1.727 \times \ln \mathrm{m}_{2}\right.$ area $\left.)\right]$ was used to calculate body masses for the fossil caenolestoids. The extinct species are estimated to have ranged in size from $13 \mathrm{~g}$ (smaller than living caenolestids) to over $1000 \mathrm{~g}$ (Table 2). Abderitids include the relatively small Pitheculites minimus $(25 \mathrm{~g})$, and the larger Abderites meridonalis (248 g). The Santacrusian caenolestids Stilotherium dissimile and Phonocdromus gracilis were probably similar in size, or even smaller than their extant relatives, with estimated body masses of 24 and $13 \mathrm{~g}$, respectively. The taxonomically more diverse palaeothentids span a broad range of sizes from the very small Palaeothentes pascuali (49 g), to Carlothentes chubutensis (1039 g), the largest known caenolestoid. The majority of palaeothentids weighed between 100-350 g.

Molar morphology.-Modern frugivores and faunivores exhibit distinct shearing values on the basis of data normalized for both tooth area (SRA data, Fig. 7) and tooth length (SRL data, Fig. 8). Although none of the fossil caenolestoids achieved the degree of molar crest development of the modern Caenolestes caniventer, many taxa appear to have been faunivorous (Table 2). Phonocdromus gracilis, Trelewthentes rothi, Palaeothentes minutus, $P$. pascuali, $P$. intermedius, $P$. lemoinei, and Propalaeothentes lepidus cluster with the modern faunivores based on both ratios. In contrast, Abderites meridonalis, Acdestis oweni, Palaeothentes marshalli, P. migueli, and Palaeothentes aratae have similar 
shearing ratios (both SRA and SRL) to modern frugivorous marsupials. The dietary proclivities of remaining species, the caenolestid Stilotherium dissimile, the abderitid Pitheculites minimus, and the palaeothentid Acdestis lemairei are more elusive as the SRA and SRL ratios yield conflicting information, indicating that perhaps these species were mixed feeders (i.e., frugivorous/faunivorous). There is no indication of folivory among caenolestoids as none of the taxa with well-developed shearing has an estimated body mass of over $600 \mathrm{~g}$.

\section{DISCUSSION}

Abderitid feeding ecology.-Among the comparisons undertaken here, the morphology and pattern of wear on the abderitid plagiaulacoid shearing complex is more similar to that of the living Phalanger than to either carpolestids or multituberculates. Multituberculates and carpolestids used their lower blades to slice and crush food items against a flattened upper tooth (Krause, 1982; Biknevicius, 1986), which resulted in the apical wear characteristic of their lower blades. The difference in lower blade wear patterns between the two groups can be attributed to the unique antero-posterior component in the multituberculate masticatory cycle (Krause, 1982). In contrast, abderitid blades appear to have functioned more like those of Phalanger by shearing food items as the blades moved past each other.

Phalanger species are frugivore-omnivores that eat primarily fruits and seeds, but also consume leaves, blossoms, and nectar (Flannery, 1995; Strahan, 1995). Other living marsupials with a similar blade-to-blade plagiaulacoid shearing complex include bettongs, Hypsiprymnodon (the musky rat-kangaroo) and Burramys (the mountain pygmy possum). The diets of these species are equally broad and include roots, fruit, grass, seeds, fungus, and insects (Christensen, 1980; Burbidge et al., 1988; Smith and Broome, 1992; Taylor, 1992; Flannery, 1995; Strahan, 1995). Clearly, the simple presence of a double-bladed shearing complex does not imply a specific dietary strategy. Indeed, an investigation of premolar shearing morphology in phalangeroid marsupials suggested tendencies ranging from folivory to insectivory (Kay and Hylander, 1978).

Based on observations of feeding behavior in Bettongia (Parker, 1977), Hypsiprymnodon (Strahan, 1995), and Burramys (Dimpel and Calaby, 1972) the sectorial complex is used when feeding on hard or tough foods. Straw, nuts, and hard-bodied insects are initially broken down with bites centered over the sectorial teeth. Elongated shearing blades are also effective in subdividing ductile, weak, and pliant foods that are easily bent and stretched (see review in Strait, 1997). In contrast to the common assumption that highly derived teeth are indicative of a narrowly specialized diet, it seems likely that the specialized $\mathrm{P} 4 / \mathrm{m} 1$ complex of abderitids effectively increased the range of foods available to them. Parker's description of the plagiaulacoid complex in bettongs as "a morphological specialization to be a feeding generalist" (1977, p. 200) may also apply to abderitids.

Abderitid diversity, abundance, and evolution.-Abderites meridionalis and Pithiculites minimus are the only abderitid species known from the Pinturas Formation, and only A. meridionalis is represented at the Santa Cruz Formation localities of Monte Observación and Monte León. Abderites in particular is present within a temporal sequence spanning approximately three million years (Fleagle et al., 1995). Figure 9 illustrates changes in $\mathrm{m} 2$ area for both species against the relative temporal sequence established for the Pinturas, Monte Observación, and Monte León localities (Bown and Fleagle, 1993). Plots based on $\mathrm{m} 1, \mathrm{~m} 3$, and $\ln (\mathrm{m} 1 \mathrm{area} / \mathrm{m} 2$ area) illustrate the same general pattern. (Note that several specimens from Estancia El Carmen (11), Monte Observación (1), and Monte León (2) are not included in Fig. 9 due to incomplete provenience data.)

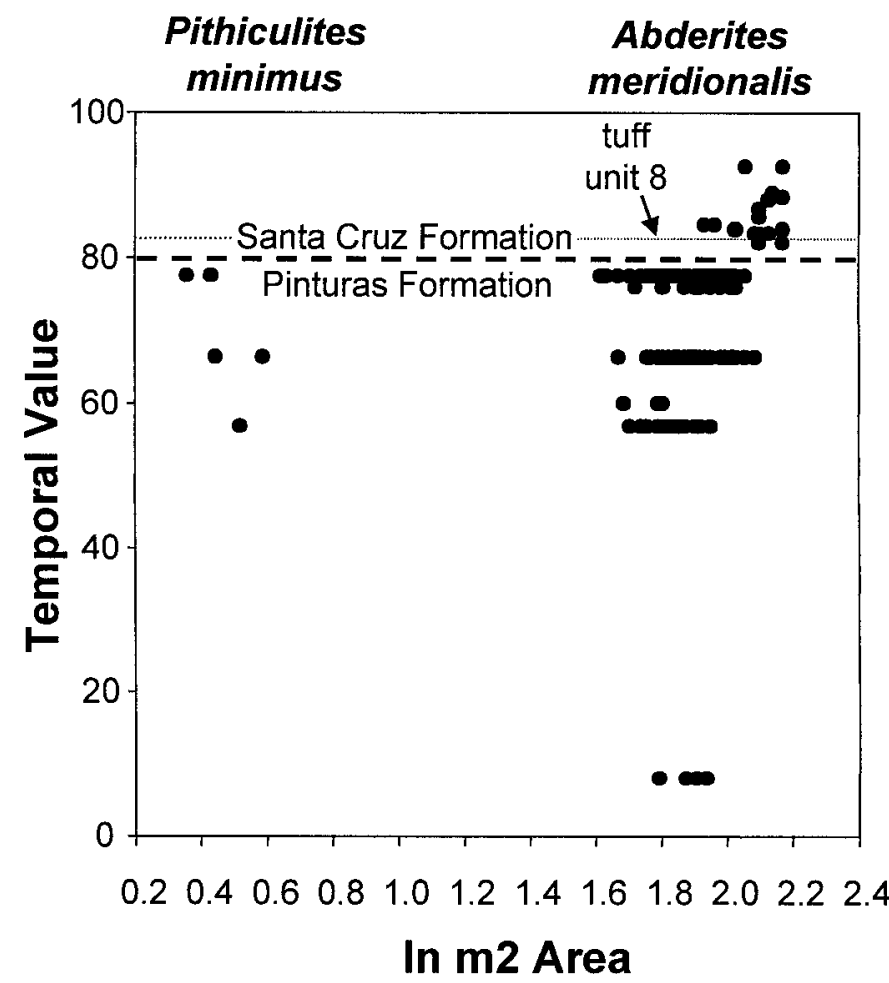

FIGURE 9-The natural log of $\mathrm{m} 2$ area for Pithiculites minimus (left) and Abderites meridionalis (right) and from Pinturas and Santa Cruz Formation localities plotted against the relative temporal value sequence presented by Bown and Fleagle (1993). The location of tuff unit 8 is based on Anderson et al. (1996).

Throughout the temporal sequence of the Pinturas Formation, A. meridionalis exhibits little change in tooth area. There is, however, an abrupt increase in lower molar size in Abderites at the base of the Santa Cruz Formation. Anderson et al. (1995) report a similar shift in body size in an octodontoid rodent (Spaniomys sp.) and a palaeothentid marsupial (Acdestis oweni) just above the base of the Santa Cruz Formation in association with a significant volcanic event (tuff unit 8, Fig. 9). For those taxa, catastrophic volcanic activity appears to have created a situation in which a combination of population bottlenecks, founder effects, and strong selective pressures resulted in punctuated morpholgical shift toward larger tooth size. Although the data are limited, the same does not appear to hold for Abderites. The two specimens from below the tuff layer are similar in size to those occuring later in the sequence. Exactly what factors mediated the size shift within the A. meridionalis lineage is unclear; temporal, geographic, and enviromental variation are all possibilities.

One way to formally recognize the two size classes would have been to attribute Pinturas and Santa Cruz Formation specimens to separate species. A simlar degree of size change within lineages of Eocene primates from North America have lead several workers to point out the difficulty of identifying species boundaries within continuous stratigraphic sequences (e.g., Bown and Rose, 1987; Rose and Bown, 1986). Whereas a complete record may reveal specimens with intermediate features that require arbitrary species designations, gaps in the fossil record can give the inaccurate impression of clear species distinctions. In the case of $A$. meridionalis, the variation in morphology between specimens from the Pinturas and Santa Cruz Formations may be the result of gaps in the geographic and/or temporal representation of the species. Certainly the most compelling support for retaining all 
the specimens in a single species is the lack of morphological variation other than size. Based on the available evidence, A. meridionalis is best described as a widespread lineage in which tooth size varies over time and/or geographic distribution.

Lower molar size of $P$. minimus is essentially stable within the Pinturas Formation. Although a slight size reduction over time may be present, the sample is too limited to confirm the trend. The presence of $P$. minimus at Pinturas is consistent with both the presence of other Colhuehuapian taxa there, and fits with the radiometric data indicating that the Pinturas Formation is slightly older than the Santa Cruz Formation (Bown and Fleagle, 1993; Fleagle et al., 1995). Wherever it is found, Pithiculites is rare and its absence at Monte Observación and Monte León may simply reflect the overall dearth of abderitids at those localities. Unlike Abderites which is known only through the Santacrucian land mammal age, Pithiculites is represented by a single specimen of $P$. chenche in the more recent (LaVentan) Honda Formation of Colombia (Dumont and Bown, 1997; Flynn et al., 1997).

In contrast to the abderitids, palaeothentids from Pinturas, Monte Observación, and Monte León are represented by eight genera and 17 species (Bown and Fleagle, 1993). The underlying cause for this disparity in species diversity is not immediately clear as abderitids and palaeothentids are similar sized animals and both exhibit a specialized $\mathrm{P} 4 / \mathrm{m} 1$ shearing complex. However, there are striking differences between the two families. Abderitids exhibit extreme specialization of the shearing teeth, whereas in palaeothentids there is a greater diversity in molar shearing crest development. In contrast to the laterally compressed, bladelike, and serrated $\mathrm{m} 1$ trigonid of abderitids, palaeothentid first molars exhibit subtle elongation of the $\mathrm{m} 1$ paracristid while the metaconid is retained (Bown and Fleagle, 1993). As discussed above, the exaggerated shearing blades of abderitids may have functioned as multi-purpose cutting/fracturing tools that enabled them to utilize a wide variety of food items. In contrast, the molar shearing morphology of palaeothentids suggests a greater diversity in dietary specializations than are seen in Abderites and Pithiculites.

In terms of morphological and inferred behavioral specializations, abderitids may be viewed as generalists that exhibited morphological stasis over time. Palaeothentids, on the other hand, were specialists exhibiting greater morphological plasticity and experienced more frequent speciation events. Indeed, the intraspecific morphological shifts associated with pyroclastic events seen among palaeothentids at Monte Observación (Bown and Fleagle, 1993) are not present within the abderitid sample. In sum, abderitids and palaeothentids can be described respectively as eurytopic and stenotopic lineages in regard to dietary adaptations and species diversity (sensu Vrba, 1980).

Another interesting pattern to emerge from these collections is the substantial difference in caenolestoid faunal composition between Pinturas and Santa Cruz Formation localities. At Pinturas the minimum number of individuals (MNI) for abderitids is 168, whereas the palaeothentid MNI is 37 (Bown and Fleagle, 1993). In contrast, at Monte Observación and Monte León the MNI is 15 for abderitids and 151 for palaeothentids (Bown and Fleagle, 1993). Temporal variation is one possible cause for differences in caenolestoid composition in the two areas. The relative abundance of abderitids may have decreased over time while that of palaeothentids increased. Geographic variables are another possible source of variation. The mammalian and avian fauna of the two areas were disparate and may indicate that the two regions offered different types of caenolestoid niches. Finally, the Pinturas Formation is approximately 250 to $300 \mathrm{~km}$ inland, while Monte Observación and Monte León are located on the coast. Because the localities are well separated, differences in caenolestoid faunal composition may simply reflect geographic isolation.

\section{SUMMARY AND CONCLUSIONS}

The diverse radiation of caenolestoid marsupials from the Santacrucian Land Mammal Age of southern Argentina contained species ranging in size from approximately 8 to over $1,000 \mathrm{~g}$. Although all modern caenolestids are faunivores, the Miocene fauna included both frugivores and faunivores, as well as mixed feeders. Abderitids and palaeothentids, the two main groups of Santacrucian caenolestoids, differ dramatically in both species diversity and inferred dietary strategies.

All Miocene abderitids can be placed into four species, Abderites meridionalis, A. pristinus, Pithiculites minimus, and P. chenche. Based on the development of molar shearing crests and reconstructed body mass, Abderites was primarily frugivorous while the much smaller Pithiculites probably consumed a mixture of plant and animal material. All abderitids possess a well-developed double-bladed $\mathrm{P} 4 / \mathrm{m} 1$ shearing complex. Based on comparisons to Phalanger orientalis, a modern marsupial with a similar shearing system, this striking adaptation probably allowed abderitids to initiate the breakdown of foods, including those that were hard and/ or tough. Because this unique specialization would have permitted a varied diet, abderitids can be viewed as dietary generalists.

In contrast, palaeothentids were more specious, exhibited a wider range in body mass, and encompassed a broader range of dietary strategies than abderitids. Importantly, palaeothentids lacked a highly specialized $\mathrm{P} 4 / \mathrm{m} 1$ shearing complex. Without this tool for breaking down hard/tough food items, the foods available to palaeothentids were probably more constrained to those delimited by design of their molar teeth. Because of these limitations, palaeothentids are interpreted to be dietary specialists.

The more generalized abderitids exhibit a long period of morphological stasis. Pithiculites minimus is limited to the Pinturas Formation, whereas Abderites meridionalis ranges through both the Pinturas and Santa Cruz Formations. Based on their generalized morphology, low species diversity, and stability over time, abderitids can be desribed as a eurytopic lineage. In constrast, palaeothentid species generally exhibit shorter geological ranges, greater species diversity, and appear to have been strongly affected by local environmental fluctuations (Bown and Fleagle, 1993). These features, coupled with the potentially more specialized and diverse diets than seen among abderitids, mark the palaeothentids as a stenotopic lineage. In essence, the abderitid and palaeothentid lineages illustrate markedly different evolutionary strategies among two closely related lineages of broadly similar animals.

\section{ACKNOWLEDGMENTS}

We extend our thanks to the following individuals for their contributions to this project: J. Bonaparte, T. Bown, L. Chiappe, M. Cozzuol, T. Dozo, J. Fleagle, I. Horovitz, G. Ortiz, and M. Soria. We also thank the following museums for access to specimens in their collections: the American Museum of Natural History (New York); the Museo Argentino Ciencias Naturales "Bernardino Rivadavia" (Buenos Aires); the Museum of Comparative Zoology (Boston), the British Museum of Natural History (London), the National Museum of Papua New Guinea (Port Moresby), and the University of Kansas (Lawrence). Fieldwork was supported by grants from the National Geographic Society (244082 ) and the National Science Foundation (BNS-82-10949, BNS86-06796, BNS-90-12154) to J. G. Fleagle. Laboratory analysis was supported by grants from the National Science Foundation to E. R. Dumont (IBN-9507488) and S. G. Strait (BNS-90-01652). Illustrations were skillfully rendered by L. Byrne.

\section{REFERENCES}

Ameghino, F. 1887. Enumeración sistemática de las especies de mammíferos fóssiles coleccionados por Cárlos Ameghino en los terranos 
eocenos de la Patagonia austral y depositados en el Museo La Plata. Boletin Museo de La Plata, 1:1-26.

Ameghino, F. 1889. Contribución al conocimiento de los mammíferos fóssiles de la República Argentina, obra escrita bajo los auspicios de la Acadamia Nacional de Ciencias de la República Argentina para preentarla a la Exposicion Universal de Paris de 1889. Acta Academia de las Ciencias de Córdoba, 6:1-1027.

AMEGHINO, F. 1890. Los plagiaulacideos argentinos y sus relaciones zoológicas, geológicas y geográficas. Instituto Geográfico Argentino, Boletín, 11:143-201.

Ameghino, F. 1891a. Mamiferos y aves fósiles argentinas. Especies neuvas, adiciones y correciones. Revista Argentina de Historia Natural, 1: 240-259.

AMEGHINO, F. 1891b. Nuevos restos de mammíferos fóssiles descubiertos por Cárlos Ameghino en el Eocene inferior de la Patagonia austral. Especies neuvas, adiciones y correciones. Revista Argentina de Historia Natural, 1:289-328.

AMEGHINO, F. 1893. Les premier mammiféres. Rélations entre les mammiféres diprotodontes éocénes de l'Amerique de Nord et ceux de la République Argentine. Revue génerale Sciences (Paris), 4:77-81.

Ameghino, F. 1894. Enuméracion synoptique des éspecies de mammifères fossiles des formations éocénes de Patagonie. Boletin de Academia de Ciencias Córdoba, 13:259-452.

Ameghino, F. 1898. Sinopsis geológico-paleontológica. Segundo censo de la Republique Argentina. Fol., Beunos Aires, 1:112-255.

Ameghino, F. 1902a. L'age des formations sédimentaires de Patagonia. Anales de Sociedad de Ciencias argentinas, 54:161-180, 220-249, 283-342.

AMEGHINO, F. 1902b. Premiére contribution à la connaissance de la faune mammalogique des couches à Colpodon. Academia Nacional de Ciencas de Córdoba, Boletín, 17:71-141.

AMEGHINO, F. 1903. Los diprotodontes del orden de los plagiaulacoideos y el origen de los roedores y de los polimastodontes. Anales del Museo Nacional, Ser. 3, 1:81-192.

Ameghino, F. 1904. Paleontologia argentina. Publicaciones de la Universidad de La Plata. Facultad de Ciencias Físico-matemáticas, 2:1-79.

Ameghino, F. 1906. Les formations sédimentaires du Crétacé supérieur et du Tertiare de Patagonie avec un paralléle entre leurs faunes mammaligiques et celles de l'ancien continent. Anales del Museo Nacional, Ser. 3, 8:1-568

Anderson, D. K., J. Damuth, And T. M. Bown. 1995. Rapid morpholgical change in Miocene marsupials and rodents associated with a volcanic catastrophe in Argentina. Journal of Vertebrate Paleontology, 15(3):640-649.

BiKnevicius, A. R. 1986. Dental function and diet in the carpolestidae (Primates, Plesiadapiformes). American Journal of Physical Anthropology, 71:157-171.

Bown, T. M., AND J. G. Fleagle. 1993. Systematics, biostratigraphy, and dental evolution of the Palaeothentidae, later Oligocene to earlymiddle Miocene (Deseadan-Santacrucian) caenolestoid marsupials of South America. The Paleontological Society Memoir, 29, 76 p.

Bown, T. M., AND C. N. LARRIESTRA. 1990. Sedimentary paleoenvironments of fossil platyrrhine localities, Miocene Pinturas Formation, Santa Cruz Province, Argentina. Journal of Human Evolution, 19:87-119.

Bown, T. M., AND K. D. Rose. 1987. Patterns of dental evolution in early Eocene Anaptomorphine primates (Omomyidae) from the Bighorn Basin, Wyoming. The Paleontological Society Memoir, 23, $162 \mathrm{p}$.

Burbidge, A. A., K. A. Johnson, P. J. Fuller, And R. I. Southgate. 1988. Aboriginal knowledge of the mammals of the central deserts of Australia. Australian Wildlife Research, 15:9-39.

Christensen, P. E. S. 1980. The biology of Bettongia penicillata (Gray, 1837) and Macropus eugenii (Desmarest, 1817) in relation to fire. Bulletin of the Forests Department of Western Australia, 91:1-90.

CraIG, S. A. 1985. Social organization, reproduction, and feeding behaviour of a population of yellow-bellied gliders, Petaurus australis (Marsupialia: Petauridae). Australian Wildlife Research, 12:1-18.

Damuth, J., AND B. J. Macfadden. 1990. Body Size in Mammalian Paleobiology: Estimation and Biological Implications. Cambridge University Press, Cambridge, 397 p.

Dimpel, H., AND J. H. CALABY. 1972. Further observations on the mountain pygmy possum (Burramys parvus). Victorian Naturalist, 89(4): 101-106.
Dumont, E. R., AND T. M. Bown. 1997. New caenolestoid marsupials, p. 207-212. In R. F. Kay, R. H. Madden, R. L. Cifelli, and J. J. Flynn (eds.), Vertebrate Paleontology in the Neotropics: The Miocene Fauna of La Venta, Colombia. Smithsonian Institution Press, Washington, $592 \mathrm{p}$.

FlanNery, T. 1995. Mammals of New Guinea. Cornell University Press, Ithaca, $568 \mathrm{p}$.

Fleagle, J. G. 1978. Size distributions of living and fossil primate faunas. Paleobiology, 4:67-76.

Fleagle, J. G., T. M. Bown, C. Swisher, And G. Buckley. 1995. Age of the Pinturas and Santa Cruz formations. VI Congreso Argentino de Paleontologia y Biostratigragia, Actas:129-135, Trelew.

FlynN, J. J., J. Guerrero, AND C. A. Swisher. 1997. Geochronology of the Honda Group, p. 44-66. In R. F. Kay, R. H. Madden, R. L. Cifelli, and J. J. Flynn (eds.), Vertebrate Paleontology in the Neotropics: The Miocene Fauna of La Venta, Colombia. Smithsonian Institution Press, Washington, $592 \mathrm{p}$.

GibSON, D. F., AND J. R. ColE. 1992. Aspects of the ecology of the mulgara Dasycercus cristicauda, (Marsupialia: Dasyuridae) in the Northern Territory. Australian Mammalogy, 15:105-112.

Illiger, C. 1811. Prodromus systematis mammalium et avium additis terminis zoographicis utrudque classis. C. Salfeld, Berlin, $301 \mathrm{p}$.

JUNGERS, W. L. 1990. Problems and methods in reconstructing body size in fossil primates, p. 103-118. In J. Damuth and B. J. MacFadden (eds.), Body Size in Mammalian Paleobiology: Estimation and Biological Implications. Cambridge University Press, Cambridge.

KAY, R. F. 1975. The functional adaptations of primate molar teeth American Journal of Physical Anthropology, 42:195-215.

KAY, R. F. 1984. On the use of anatomical features to infer foraging behavior in extinct primates, p. 21-53. In P. S. Rodman and J. G. H. Cant (eds.), Adaptations for Foraging in Nonhuman Primates: Contributions to an Organismal Biology of Prosimians, Monkeys, and Apes. Colombia University Press, New York, $351 \mathrm{p}$.

KAY, R. F., AND H. H. CoverT. 1986. Anatomy and behavior of extinct primates, p. 467-508. In D. J. Chivers, B. A. Wood, and A. Bilsborough (eds.), Food Acquisition and Processing in Primates. Plenum Press, New York, 576 p.

KAY, R. F., AND K. HiIEMAE. 1974. Mastication in Galago crassicaudatus: A cinefluorographic and occlusal study, p. 501-530. In R. D. Martin, G. A. Doyle, and A. C. Walker (eds.), Prosimian Biology. University of Pittsburgh Press, 983 p.

KAY, R. F., AND W. L. HYLANDER. 1978. The dental structure of mammalian folivores with special reference to Primates and Phalangeroidea, p. 173-191. In G. G. Montgomery (ed.), The Ecology of Arboreal Folivores. Smithsonian Institution Press, Washington, 574 p.

KIRSCH, J. A. W., AND P. F. WALlER. 1979. Notes on the trapping and behavior of the Caenolestidae (Marsupialia). Journal of Mammalogy, 60:390-395.

Kraglievich, J. L. 1953. Contribuciones al conocimiento de los Primates fósiles de la Patagonia. Anales Museo de Nahuel Huapi, 3:37-62.

KrausE, D. W. 1982. Jaw movement, dental function, and diet in the Paleocene multituberculate Ptilodus. Paleobiology, 8:265-281.

LYNE, A. G. 1964. Observations on the breeding and growth of the marsupial Perameles nasuta Geoffroy, with notes on other bandicoots. Australian Journal of Zoology, 12:322-339.

MaCMiLlen, R. E., AND T. J. DAwson. 1986. Energy and water metabolism of the kowari Dasyuroides byrnei (Marsupialia: Dasyuridae), while resting and running. Australian Mammalogy, 9:87-95.

Marshall, L. G. 1976. Revision of the South American Fossil Marsupial subfamily Abderitinae (Mammalia, Caenolestidae). Publicaciones del Museo Municipal Ciencas Naturales "Lorenzo Scaglia", 2:57-89.

Marshall, L. G. 1980. Systematics of the South American marsupial family Caenolestidae. Fieldiana (Geology), 5:1-145.

Marshall, L. G. 1990. Fossil Marsupialia from the type Friasian land mammal age (Miocene), Alto Rio Cisnes, Aisen, Chile. Revista Geológia de Chile, 17:19-55.

Marshall, L. G., AND R. Pascual. 1977. Neuvos marsupiales caenolestidae del "Piso Notohihidense" (SW de Santa cruz, Patagonia) de Ameghino. Sus Aportaciones a la chronologia y evolucion de las cominidades de mamiferos sudamericanos. Publicaciones del Museo Municipal de Ciencias Naturales de Mar del Plata "Lorenzo Scaglia", 2(4):91-122

Marshall, L. G., R. E. Drake, G. H. Curtis, R. F. Butler, K. M. 
Flanagan, ANd C. W. Naeser. 1986. Geochronology of Type Santacrucian (Middle Tertiary) Land Mammal Age, Patagonia, Argentina. Journal of Geology, 94:449-457.

Morton, S. R. 1978. An ecological study of Sminthopsis crassicaudata (Marsupialia: Dasyuridae) I. Distribution, study areas, and methods. Australian Wildlife Research, 5:151-162.

Nagy, K. A., R. S. Seymour, A. K. Lee, and R. Braithwaite. 1978. Energy and water budgets in free-living Antechinus stuartii (Marsupialia: Dasyuridae). Journal of Mammalogy, 59(1):60-68.

PARKER, P. J. 1977. Aspects of the Biology of Bettongia penicillata. Unpublished Ph.D. dissertation, Yale University, New Haven, 222 p.

Paula Couto, C. de. 1952. Fossil mammals from the beginning of the Cenozoic in Brazil. Marsupialia: Polydolopidae and Borhyaenidae. American Museum Novitates, 1559:1-27.

Peters, R. H. 1983. The Ecological Implication of Body Size. Cambridge University Press, Cambridge, 392 p.

RaE, T. C., T. M. Bown, and J. G. Fleagle. 1996. New palaeothentid marsupials (Caenolestoidea) from the early Miocene of patagonian Argentina. American Museum Novitates, 3164:1-10

REIG, O. 1955. Un nuevo género y especie de caenolestinos del Plioceno de la provincia de Buenos Aires (Republica Argentina). Revista Asociación Geológico de Argentina, 10:60-71.

Rose, K. D., AND T. M. Bown. 1986. Gradual evolution and species designation in the fossil record. Contributions to Geology, University of Wyoming, Special Paper 3:119-130.

Schlosser, M. 1925. Class V. Mammalia, vol. III. In K. A. von Zittel (ed.) (Revised by M. Schlosser), Textbook of Paleontology. Macmillan and Company, London, $316 \mathrm{p}$.

SCHMIDT-NIELSEN, K. 1984. Scaling: Why is Animal Size so Important? Cambridge University Press, Cambridge, $241 \mathrm{p}$.

Simpson, G. G. 1932. Some new or little known mammals from the "Colpodon" beds of Patagonia. American Museum Novitatis, 575:112.

SimPSON, G. G. 1933. The "Plagiaulacoid" type of mammalian dentition. Journal of Mammalogy, 14:97-107.

SINClaIR, W. J. 1906. Mammalia of the Santa Cruz beds: Marsupialia. Report of the Princeton University Expedition to Patagonia, 4(3):333460 .
Smith, A. P. 1982. Diet and feeding strategies of the marsupial sugar glider in temperate Australia. Journal of Animal Ecology, 51:149-166.

SMITH, A. P. 1984. Demographic consequences of reproduction, dispersal and social interaction in a population of leadbeaters possum (Gymnobelideus leadbeateri), p. 359-373. In A. P. Smith and I. D. Hume (eds.), Possums and Gliders. Surrey Beatty and Sons, Chipping Norton, Australia.

Smith, A. P., And L. Broome. 1992. The effects of season, sex and habitat on the diet of the mountain pygmy-possum (Burramys parvus). Wildlife Research, 19:755-768.

Smith, A. P., AND A. LeE. 1984. The evolution of strategies for survival and reproduction in possums and gliders, p. 17-34. In A. Smith and I. Hume (eds.), Possums and Gliders. Surrey Beatty and Sons, Chipping Norton, Australia.

StRAHAN, R. 1995. Mammals of Australia. Smithsonian Institution Press, Washington, $756 \mathrm{p}$.

StRAit, S. G. 1993a. Differences in occlusal morphology and molar size in frugivores and faunivores. Journal of Human Evolution, 25:471484.

STRAIT, S. G. 1993b. Molar morphology and food texture among smallbodied insectivorous mammals. Journal of Mammalogy, 74:391-402.

Strait, S. G. 1997. Tooth use and the physical properties of food. Evolutionary Anthropology, 5:199-211.

TAYLOR, M. E., AND A. G. HANNAM. 1987. Tooth microwear and diet in the African Viverridae. Canadian Journal of Zoology, 65:1696-1702.

TAYLOR, R. J. 1992. Seasonal changes in the diet of the Tasmanian bettong (Bettongia gaimardi), a myrmycophagous marsupial. Journal of Mammalogy, 73:408-414.

TURNER, V. 1984. Eucalyptus pollen in the diet of the feathertail glider, Acrobates pygmaeus (Marsupialia: Burramyidae). Australian Wildlife Research, 11:77-81.

VRBA, E. S. 1980. Morphological and environmental change: How do they relate in time? South African Journal of Science, 72(2):61-84.

WARD, S. J. 1990. Life history of the Eastern pygmy-possum Cercartetus nanus (Burramyidae: Marsupialia) in South-eastern Australian. Australian Journal of Zoology, 38:287-304.

ACCEPTED 29 JUNE 2000 